\title{
IMPLEMENTASI SISTEM PENDUKUNG PENGAMBILAN KEPUTUSAN PADA PEMBELIAN BAHAN OLAHAN KARET DARI PEMASOK
}

\author{
Ridha Luthvina \\ Politeknik Akademi Teknologi Industri Padang \\ E-Mail: ridhaluthvina@gmail.com \\ Rika Ampuh Hadiguna \\ Universitas Andalas Padang \\ Jonrinaldi \\ Universitas Andalas Padang
}

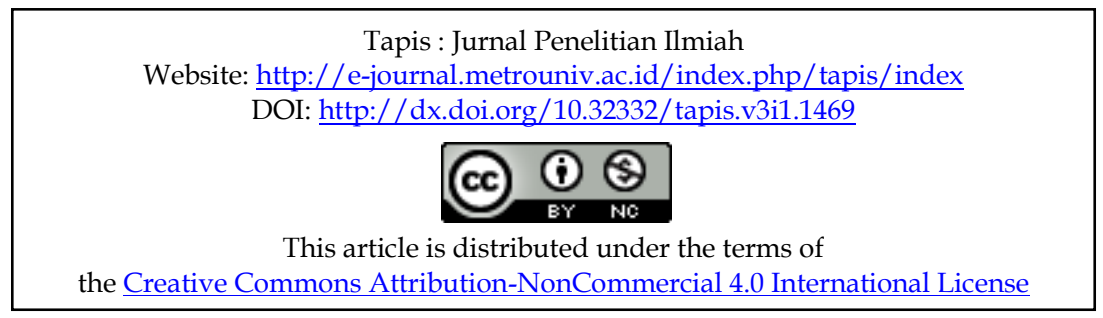

\begin{abstract}
The need for high-quality crumb rubber in West Sumatra tends to increase. However, the amount and quality of rubber from suppliers belong to weak caused by the bad monitoring systems, the supply cannot be met properly, and there is a lot of shrinkage in rubbers purchased by the company. Therefore this research was carried by implementing the Decision Support System (DSS) which was expected to help facilitate supplier data searches and evaluate the supplier's performance. The first stage in this research was designing DSS included the use of Unified Modeling Language (UML) diagram and database design. Next, built an applicable software using Personal Home Page (PHP), My Structured Query Language (MySQL), and Apache. An advantage of DSS designed was to accommodate differences and changes in rubber supplier assessment criteria according to the consideration of each crumb rubber industry in West Sumatra. There were 3 of 11 main crumb rubber criteria assessed. The results of these 3 criteria were obtained highest weight, namely Dryness (0.18), cleanliness (0.15), and consistency of quality (0.10). While the previous performance obtained the lowest weight (0.05). This meant that the criteria of dryness, cleanliness, and consistency of quality, will be the main considerations for companies in ranking and evaluating suppliers who work with companies.
\end{abstract}

Keywords: Crumb Rubber, DSS, PHP, MySQL

\begin{abstract}
Abstrak
Permintaan terhadap karet remah (crumb rubber) di Sumatera Barat cenderung meningkat. Namun karena lemahnya sistem pengawasan jumlah dan kualitas bahan olah karet (bokar) dari pemasok mengakibatkan pasokan tidak dapat terpenuhi dengan baik, dan banyak terjadinya penyusutan bahan baku yang dibeli perusahaan.
\end{abstract}


Oleh karena itu penelitian ini dilakukan dengan mengimplementasikan alat bantu pengambilan keputusan penilaian pemasok bokar - Decision Support System (DSS) - yang diharapkan dapat membantu memudahkan pencarian data pemasok dan mengevaluasi kinerja pemasok tersebut. Tahapan pertama pada penelitian ini adalah perancangan DSS yang meliputi perancangan sistem menggunakan Unified Modeling Language (UML) diagram dan perancangan database. Selanjutnya masuk ke tahap pembuatan aplikasi perangkat lunak menggunakan Personal Home Page (PHP), My Structured Query Language (MySQL), dan apache. Salah satu kelebihan DSS yang telah dirancang yaitu dapat mengakomodasi perbedaan dan perubahan kriteria penilaian pemasok bokar sesuai pertimbangan setiap industri crumb rubber di Sumatera Barat. Dari 11 subkriteria kualitas karet remah yang dipilih, diperoleh hasil 3 kriteria dengan bobot tertinggi yaitu Kadar Karet Kering (KKK) $(0,18)$, kebersihan bokar $(0,15)$, dan konsistensi kualitas $(0,10)$. Sedangkan kinerja sebelumnya memperoleh bobot terendah $(0,05)$. Artinya kriteria dengan bobot tertinggi seperti KKK, kebersihan bokar, dan konsistensi kualitas, akan menjadi pertimbangan utama bagi perusahaan dalam merangking serta mengevaluasi pemasok yang bekerjasama dengan perusahaan.

Kata Kunci: Karet Mentah, DSS, PHP, MySQL

\section{A. PENDAHULUAN}

Menurut data Bank Dunia tahun 2015, Indonesia merupakan negara kedua penghasil karet alami terbesar di dunia. Karet jenis SIR 20 atau dalam perdagangan Internasional dikenal dengan TSR 20, mencatatkan nilai ekspor terbesar yaitu mencapai 92\% dari total ekspor karet alam Indonesia1. Badan Pusat Statistik Propinsi Sumatera Barat pada tahun 2016 mencatatkan golongan karet dan barang dari karet memberikan peran sebesar 20,78 persen terhadap nilai ekspor Sumatera Barat. Industri pengolahan karet remah (Crumb Rubber) hanya bergantung pada satu bahan baku utama yaitu Bahan Olah Karet (Bokar).

Pemilihan bahan baku berpengaruh signifikan terhadap pencapaian spesifikasi yang ditetapkan oleh buyer/pelanggan. Selain penaksiran secara visual, mutu bokar dapat ditentukan dengan menguji kemurnian kadar karet yang biasanya dinyatakan sebagai kadar karet kering (K3 atau KKK). Persentase KKK digunakan oleh pabrikan untuk menaksir harga bokar yang dijual oleh pemasok.

${ }^{1}$ N Erni et al., "Rekayasa Sistem Manajemen Ahli Perencanaan Produksi Karet Spesifikasi Teknis," Inovisi 7, no. 1 (2011): 25-32. 
Besarnya nilai KKK praktis ditentukan secara kompromistik yang tidak jarang bersifat sepihak (oleh pabrik crumb rubber) dengan resiko menimbulkan ketidakpuasan bagi pihak pembeli maupun penjual. Makin besar penyimpangan terhadap KKK, akan makin besar kerugian yang ditimbulkan.

Hasil observasi terhadap beberapa pabrik crumb rubber di wilayah Sumatera Barat, produsen cenderung menerima/membeli bokar dari pemasok tanpa mempertimbangkan kapasitas teknis, kemampuan produksi dalam menyerap bahan baku, dan kualitas bokar yang diterima baik saat pembelian maupun perlakuan selama penyimpanan. Akibatnya pada periode tertentu pasokan yang diterima melebihi kapasitas gudang penyimpanan bahan baku. Namun pada periode lain pasokan bahan baku justru lebih sedikit daripada daya serap produksi.

Perusahaan masih menggunakan cara tradisional yaitu berdasarkan jumlah dan frekuensi pasokan dalam memilih pemasok Bahan Olah Karet (Bokar). Kesalahan kriteria yang dipergunakan dalam memilih pemasok akan mengakibatkan banyak terjadinya penyusutan dari bahan baku yang dibeli perusahaan ${ }^{2}$. Selain itu berdasarkan pengamatan terhadap pabrik crumb rubber yang ada di Sumatera Barat, dalam menjalankan aktivitas pembelian bokar, pencatatan penerimaan bokar masih dilakukan secara manual. Pencacatan secara manual mengakibatkan data pemasok terdahulu menjadi sulit ditelusuri.

Salah satu upaya untuk menjaga pasokan bahan olah karet baik dari sisi kualitas maupun kuantitas yaitu dengan membuat alat bantu pengambilan keputusan yang memudahkan dalam penilaian pemasok bahan olah karet dan menelusuri rekam jejak pemasok bahan olah karet yang bekerjasama dengan perusahaan.

2 Elwizalina, "Penilaian Supplier Bokar Pada PT Kilang Lima Gunung Dengan Metoda Analytical Hierarchy Process" (Sekolah Tinggi Teknologi Industri, 2008). 


\section{B. KAJIAN TEORI}

Pabrikan menghabiskan lebih dari $60 \%$ dari total penjualan pada barangbarang yang dibeli ${ }^{3}$. Oleh karena itu, apabila pemilihan pemasok dilakukan secara tepat, maka dapat mengurangi biaya pembelian secara signifikan, memperbaiki daya saing pasar dan meningkatkan kepuasan pengguna. Identifikasi dan evaluasi pemasok yang tepat memastikan perusahaan akan menerima material yang berkualitas tinggi pada harga yang masuk akal, pengiriman dengan jumlah yang tepat, pada waktu yang tepat, dan penyediaan layanan yang sangat baik dengan tujuan untuk memuaskan permintaan konsumen².

DSS merupakan "sekumpulan prosedur berbasis model yang digunakan untuk memproses dan menilai suatu data, untuk membantu manajer dalam pengambilan keputusan". Agar berhasil, sebuah sistem harus sederhana, kuat, mudah dikendalikan, adaptif, lengkap, dan mudah untuk berinteraksi dengan sistem tersebut ${ }^{5}$. Hadiguna ${ }^{6}$ mengembangkan DSS untuk menilai kinerja Manajemen Rantai Pasok Berkelanjutan.

Setiawan et al. ${ }^{7}$ merancang DSS dengan metode AHP yang diaplikasikan dalam hal pemilihan pemasok dan penilaian karyawan. Selain itu, Akbar8 juga melakukan perancangan model penilaian pemasok dalam penetapan bidder list pengadaan di PT Semen Padang dengan metode AHP. Agar memudahkan pengambilan keputusan dalam penilaian pemasok, Akbar (2015) merancang sebuah alat bantu aplikasi perangkat lunak. Pada umumnya penelitian terkait

${ }^{3}$ M.B Ayhan, "A Fuzzy Ahp Approach For Supplier Selection Problem: A Case Study In A Gearmotor Company," International Journal of Managing Value and Supply Chains (IJMVSC) 4, no. 3 (2013): 11-23.

${ }^{4}$ A Mendoza and J.A Ventura, "An Effective Method to Supplier Selection and Order Quantity Allocation," International Journal of Business and Systems Research 2, no. 1 (2008): 1-15.

${ }^{5}$ J.E Turban and T.P Liang, Decision Support System and Intelligent Systems, 7th ed. (New Delhi: Prentice Hal of India Private Limited, 2005).

${ }^{6}$ R.A Hadiguna, "Decision Support System of Performance Assessment for Sustainable Supply Chain Management," International Journal of Green Computing 4, no. 2 (2013): 24-37.

${ }^{7}$ A Setiawan and R Wijaya, Perancangan Dan Pembuatan Aplikasi Decision Support System Pada Departemen HRD Dan Pembelian Dengan Menggunakan Metode Analytical Hierarchy Process (AHP) (Surabaya: Universitas Kristen Petra, 2007).

8 P.G Akbar, "Usulan Indikator Evaluasi Pemasok Dalam Penetapan Bidder List: Studi Kasus Pengadaan Jasa PT. Semen Padang," Jurnal Optimasi Sistem Industri 14, no. 1 (2015): 39-54. 
industri crumb rubber hanya berkisar pada isu lingkungan, pemasaran, teknologi produksi, dan studi kelayakan.

Setelah DSS siap, maka perlu dilakukan verifikasi dan validasi. validasi adalah membangun sistem yang benar, artinya secara substansi sistem menunjukkan kinerja dengan level akurasi yang diterima. Verifikasi model terkomputerisasi yaitu memastikan bahwa program komputer dan implementasi dari model konseptual sudah benar. Pada penelitian ini digunakan ukuran validitas yang dikemukakan oleh Turban (Tabel 1). Selain itu, verifikasi dan validasi (pengujian sistem) juga merujuk pada persyaratan fungsional yang dilakukan menggunakan satu atau lebih pendekatan berikut ${ }^{9}$.

Tabel 1. Ukuran Validitas

\begin{tabular}{|l|l|l|}
\hline No. & Ukuran/Kriteria & Deskripsi \\
\hline 1 & Accuracy & $\begin{array}{l}\text { Seberapa baik sistem merefleksikan sistem nyata, seberapa } \\
\text { benar keilmuan yang digunakan untuk membangun model. }\end{array}$ \\
\hline 2 & Adaptability & Kemungkinan untuk mengembangan atau perubahan. \\
\hline 3 & $\begin{array}{l}\text { Adequacy } \\
\text { (completeness) }\end{array}$ & Porsi keilmuan yang digunakan pada model. \\
\hline 4 & Appeal & Seberapa baik keilmuan yang digunakan pada model. \\
\hline 5 & Breadh & Seberapa baik model adalam pengelolaan sistem. \\
\hline 6 & Depth & Derajat kerincian dari ilmu. \\
\hline 7 & Face Validity & Kredibilitas dari keilmuan. \\
\hline 8 & Generality & $\begin{array}{l}\text { Kapabilitas basis keilmuan untuk digunakan pada cakupan } \\
\text { masalah yang serupa. }\end{array}$ \\
\hline 9 & Precision & $\begin{array}{l}\text { Kepabilitas sistem meniru sebagian parameter sistem, } \\
\text { konsistensi sasaran, variabel yang dilingkupi oleh basis } \\
\text { keilmuan. }\end{array}$ \\
\hline 10 & Realism & $\begin{array}{l}\text { Menghitung variable dan hubungan yang relevan, kemiripan } \\
\text { dengan sistem nyata. }\end{array}$ \\
\hline 11 & Reliability & Fraksi yang mencakupi prediksi ahli sudah benar. \\
\hline 12 & Robustness & Sensitivitas dari kesimpulan terhadap struktur model. \\
\hline 13 & Sensitivity & Dampak perubahan basis keilmuan terhadap kualitas keluaran. \\
\hline 14 & $\begin{array}{l}\text { Technical and } \\
\text { Operational } \\
\text { Validity }\end{array}$ & $\begin{array}{l}\text { Kualitas asumsi, konteks, Batasan, dan kondisi serta } \\
\text { dampaknya terhadap ukuran lain. }\end{array}$ \\
\hline 15 & Turing Test & $\begin{array}{l}\text { Kemampuan evaluator untuk mengidentifikasi apakah } \\
\text { kesimpulan yang diperoleh dibuat oleh sistem atau user. }\end{array}$ \\
\hline 16 & Usefulness & Apakah keilmuan cukup memadai untuk mengatasi masalah. \\
\hline 17 & Validity & $\begin{array}{l}\text { Kapabilitas basis keilmuan untuk menghasilkan prediksi yang } \\
\text { benar secara empiris. }\end{array}$ \\
\hline
\end{tabular}

${ }^{9} \mathrm{D}$ Khung and H Zhu, Software Verification and Validation (Wiley Encyclopedia of Computer Science and Engineering) (London: John Wiley \& Sons, Inc, 2008). 
1. Use case based testing. Apabila use case telah dibangun berdasarkan kebutuhan sistem, maka pengujian sistem dapat dilakukan dengan menguji apakah sistem sudah memenuhi setiap use case.

2. Desk checking, programmer memeriksa program yang ditulisnya, bisa menggunakan pensil, kalkulator dan/atau alat bantu lainnya.

3. Walkthrough. Pihak yang me-review menggunakan data pengujian atau skenario tertentu pada pengoperasian perangkat lunak dan secara manual mengikuti langkah demi langkah logika sistem untuk memahami bagaimana sistem beroperasi dan kemudian mendeteksi kesalahan (error).

\section{METODOLOGI}

Input awal pada perancangan DSS adalah struktur hierarki dan model matematis yang diperoleh dari penelitian sebelumnya. Level satu pada struktur hierarki adalah rangking pemasok. Level kedua adalah kriteria utama, level ketiga adalah subkriteria, dan level keempat adalah alternatif pemasok. Adapun perancangan DSS terdiri dari 3 tahapan yaitu:

\section{Perancangan Sistem}

Perancangan sistem dilakukan menggunakan diagram-diagram UML seperti usecase diagram, usecase description, activity diagram dan deployment diagram. Diagram-diagram UML tersebut dirancang berdasarkan kebutuhan pada bagian pembelian bokar di industri crumb rubber yang diidentifikasi melalui wawancara dengan praktisi.

2. Perancangan Database

Perancangan database diawali dengan normalisasi tabel menjadi bentuk 3NF. Tabel yang akan dinormalisasi terdiri dari data profil pemasok, data penerimaan bokar, dan data penilaian pemasok. kemudian dilanjutkan dengan perancangan class diagram dan Entity Relationship Diagram (ERD).

3. Verifikasi dan Validasi

Verifikasi dan validasi dibuktikan melalui pengujian DSS ke salah satu industri crumb rubber yang menjadi objek penelitian. Teknik yang digunakan untuk verifikasi DSS yaitu use case based testing, desk checking, dan walkthrough/trace. Sedangkan untuk validasi digunakan teknik adaptability, appeal, breadth, realism/ event validity, dan usefulness. 
Adapun subjek penelitian ini adalah industri crumb rubber yang ada di Sumatera Barat, terutama praktisi yang menangani penerimaan bahan baku dan pemilihan pemasok bokar. Responden berasal dari 5 pabrik crumb rubber yang ada di Sumatera Barat yaitu PTP Lembah Karet, PT Famili Raya, PT Kilang Lima Gunung, PT Teluk Luas, dan PT Mega Sawindo. Responden dipilih berdasarkan pengalaman kerja di industri crumb rubber (lama bekerja), jabatan (setara manajer), dan background pendidikanya (bidang teknik).

Gambar 1. Tahapan Pelaksanaan Penelitian
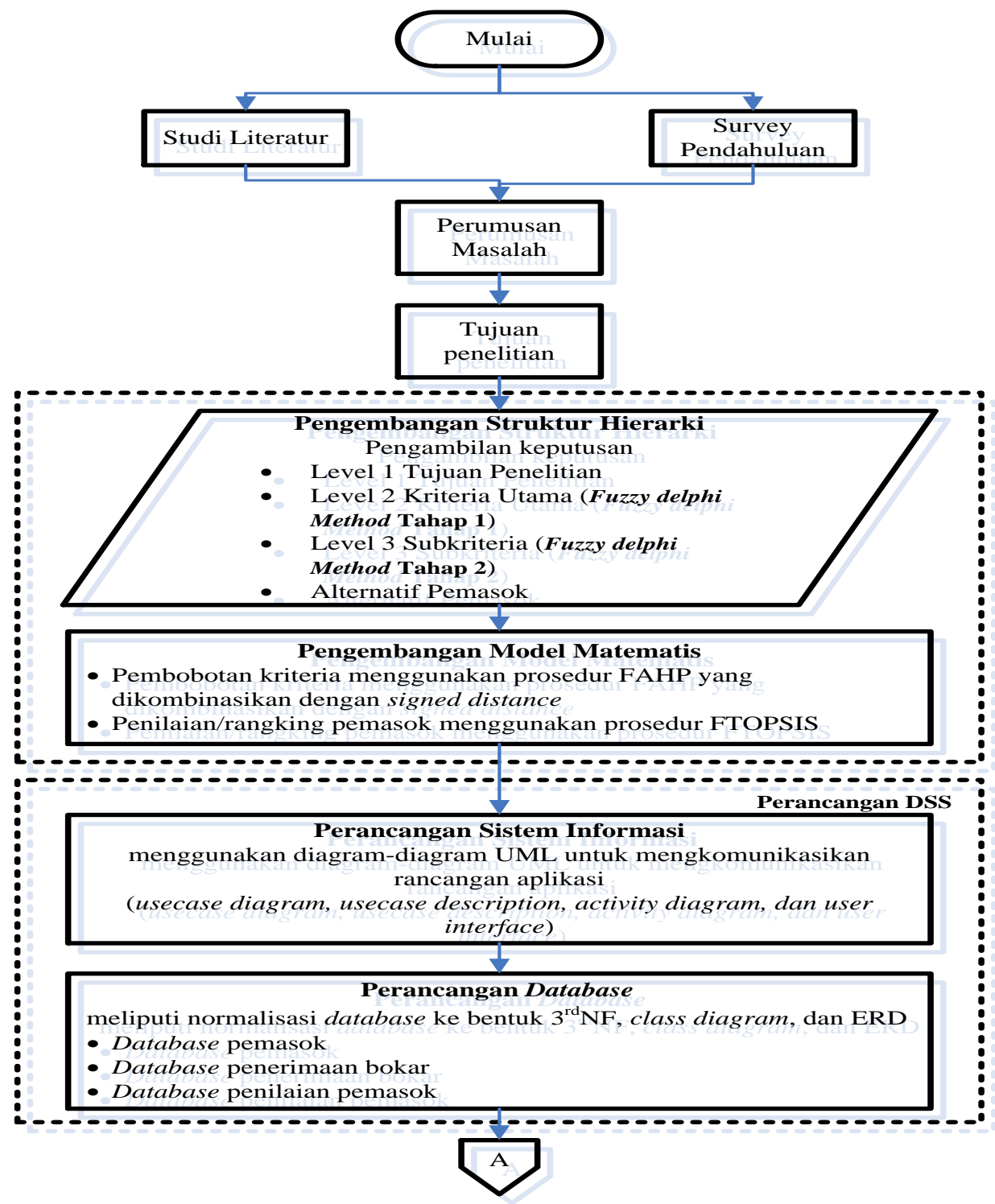
Gambar 2. Alur Pengujian DSS

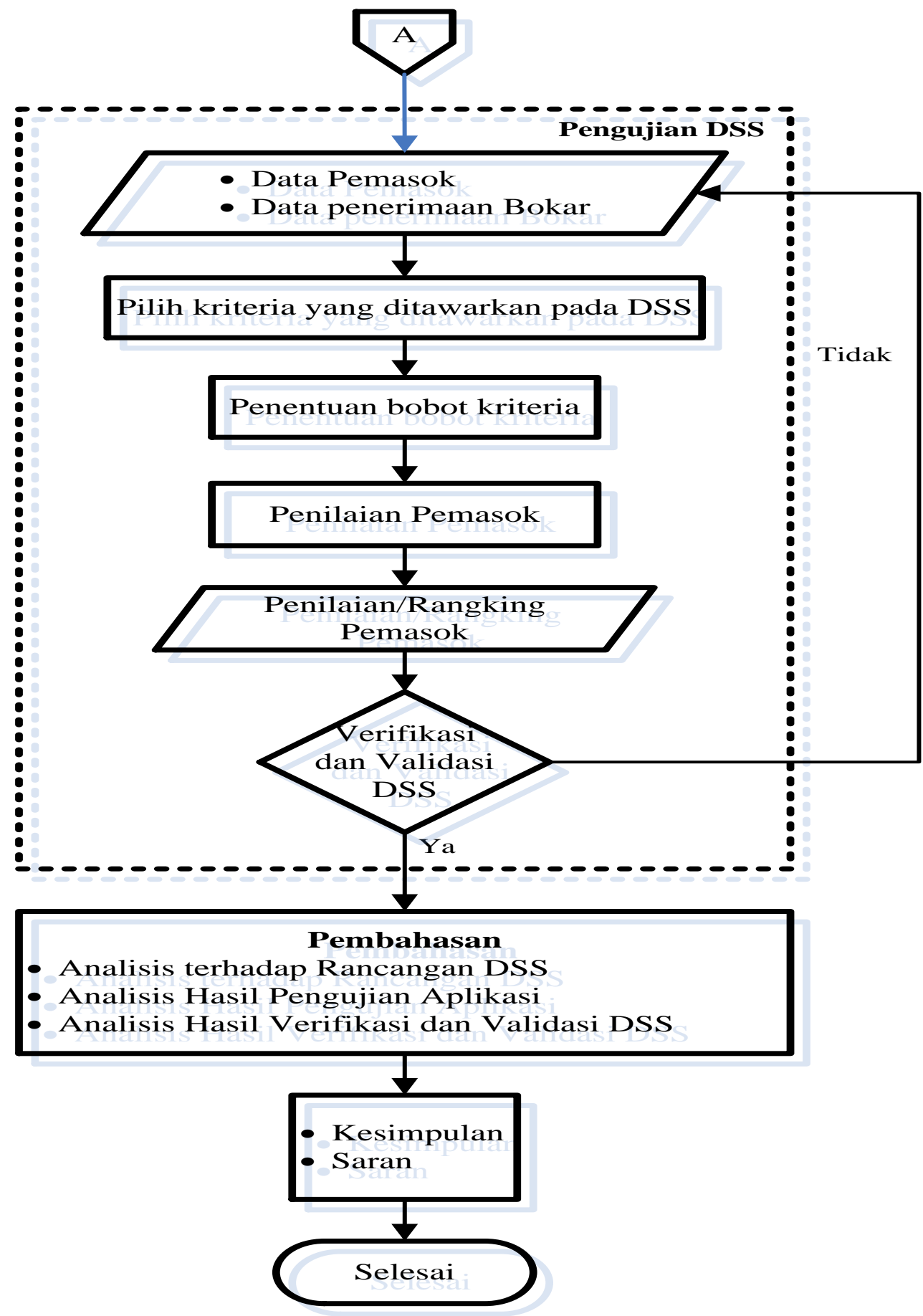

\section{HASIL DAN PEMBAHASAN}

Langkah pertama adalah analisis kebutuhan. DSS dirancang dengan tujuan untuk memenuhi kebutuhan user (industri crumb rubber) terhadap kemudahan memperoleh informasi dan dalam proses pengambilan keputusan terkait 
pemilihan pemasok bokar. Secara umum, kebutuhan akan perancangan DSS penilaian pemasok bokar adalah sebagai berikut.

1. Retrieve information element (memanggil elemen informasi). Misalnya admin dapat mencari data pemasok dengan mengetikkan ID pemasok.

2. Analyze entries files (menganalisa semua file). Tujuan utama dari perancangan DSS penilaian pemasok bokar adalah kemampuan sistem dikombinasikan dengan penilaian user dalam menganalisa kapasitas pemasok berdasarkan kriteria yang ditetapkan.

3. Prepare reports form multiple files (laporan dari beberapa file). Pada kasus penilaian pemasok bokar, dibutuhkan laporan penerimaan bokar dan laporan penilaian pemasok bokar.

4. Propose decision (menawarkan keputusan). Informasi utama yang dibutuhkan oleh industri crumb rubber yaitu daftar pemasok teratas yang memenuhi kriteria-kriteria yang ditetapkan oleh pengambil keputusan.

Gambar 3. Usecase Diagram Sistem Pembelian Bahan Olah Karet (Bokar)

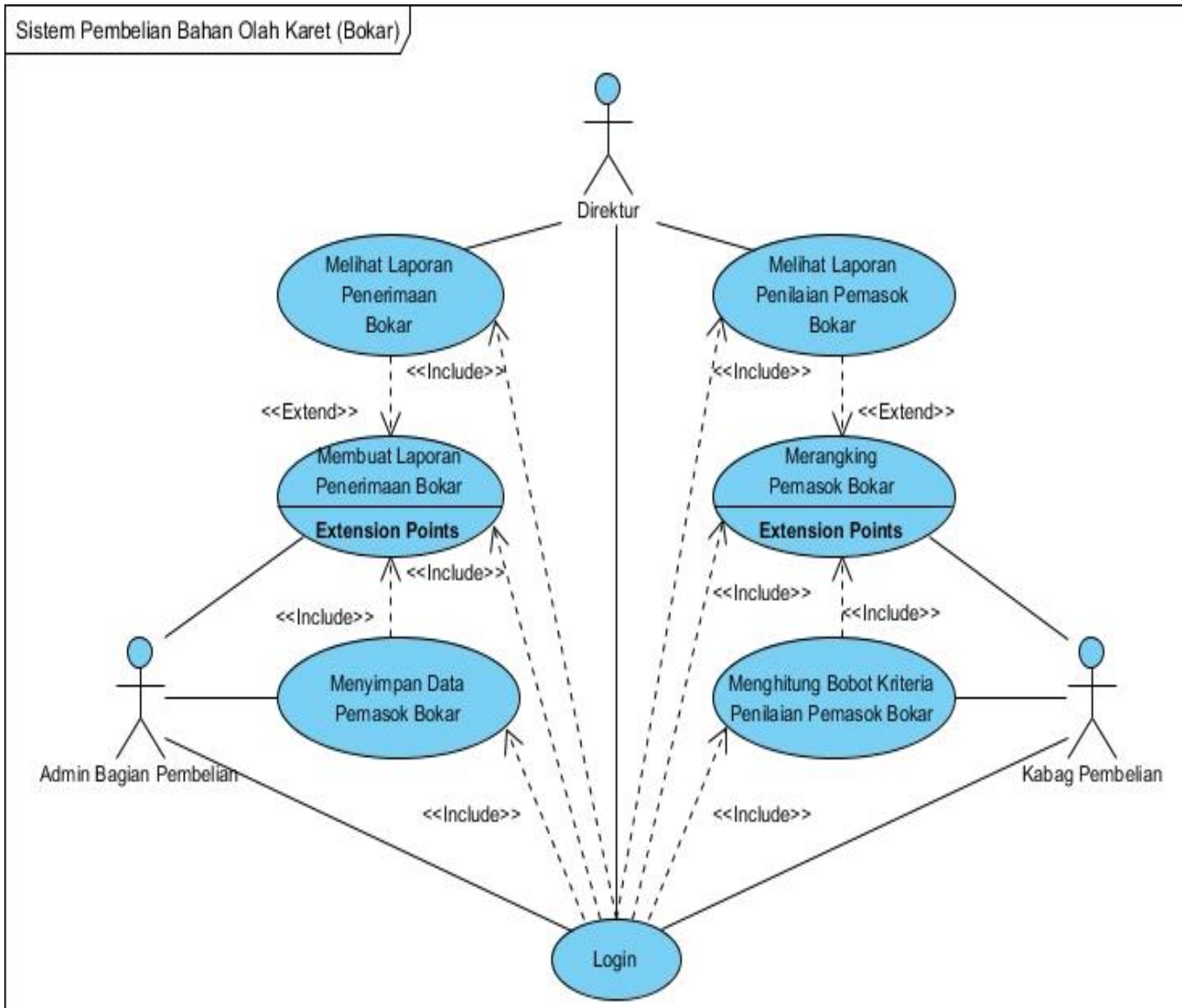


Untuk memudahkan dalam menganalisis sistem dan mengkomunikasikan rancangan sistem yang diusulkan, digunakan beberapa diagram UML yaitu usecase diagram dan activity diagram.

Tabel 2. Usecase Description Login

\begin{tabular}{|c|c|c|c|}
\hline Super Use Case & \multicolumn{3}{|c|}{ Login } \\
\hline Actor & \multicolumn{3}{|c|}{ Semua user } \\
\hline Brief Description & \multicolumn{3}{|c|}{$\begin{array}{l}\text { User memasuki sistem informasi pembelian bahan olahan karet } \\
\text { (bokar) }\end{array}$} \\
\hline Precondition & \multicolumn{3}{|c|}{ User membuka sistem/aplikasi } \\
\hline \multirow{6}{*}{ Flow of Events } & & Actor input & Sistem response \\
\hline & 1 & Membuka aplikasi & \\
\hline & 2 & & Menampilkan halaman login \\
\hline & 3 & $\begin{array}{l}\text { Mengisi username, } \\
\text { password, dan jabatan }\end{array}$ & \\
\hline & 4 & Mengklik login & \\
\hline & 5 & & $\begin{array}{l}\text { Menampilkan halaman aplikasi } \\
\text { sesuai hak akses masing-masing } \\
\text { user }\end{array}$ \\
\hline Post-conditions & \multicolumn{3}{|c|}{$\begin{array}{l}\text { User mengakses fungsi yang ada pada sistem sesuai dengan hak } \\
\text { aksesnya }\end{array}$} \\
\hline
\end{tabular}

Tabel 3. Merangking Pemasok Bokar

\begin{tabular}{|c|c|c|c|}
\hline Super Use Case & \multicolumn{3}{|c|}{ Merangking pemasok bokar } \\
\hline Actor & \multicolumn{3}{|c|}{ Kabag pembelian } \\
\hline Brief Description & \multicolumn{3}{|c|}{ Kabag pembelian memberi penilaian terhadap masing-masing pemasok } \\
\hline Precondition & \multicolumn{3}{|c|}{ Bobot masing-masing kriteria sudah ditentukan } \\
\hline \multirow{13}{*}{ Flow of Events } & & Actor input & Sistem response \\
\hline & 1 & $\begin{array}{l}\text { Memilih opsi ranking } \\
\text { pemasok }\end{array}$ & \\
\hline & 2 & & $\begin{array}{l}\text { Menampilkan form penilaian } \\
\text { pamasok }\end{array}$ \\
\hline & 3 & $\begin{array}{l}\text { Mengisi periode } \\
\text { (bulan/tahun) }\end{array}$ & \\
\hline & 4 & & $\begin{array}{l}\text { Memunculkan ID pemasom yang } \\
\text { mengirim bokar pada periode } \\
\text { tersebut }\end{array}$ \\
\hline & 5 & $\begin{array}{l}\text { Memilih salah satu ID } \\
\text { pemasok }\end{array}$ & \\
\hline & 6 & $\begin{array}{l}\text { Memilih satu kriteria dan } \\
\text { memberi nilai pemasok }\end{array}$ & \\
\hline & 7 & Mengklik save & \\
\hline & 8 & & $\begin{array}{l}\text { Menyimpan penilaian pemasok } \\
\text { berdasarkan kriteria tersebut }\end{array}$ \\
\hline & 9 & $\begin{array}{l}\text { Mengulangi skenario } 6 \text { dan } 7 \\
\text { untuk kriteria lainnya }\end{array}$ & \\
\hline & 10 & $\begin{array}{l}\text { Mengulangi scenario 5, 6, } 7 \\
\text { untuk pemasok lainnya }\end{array}$ & \\
\hline & 11 & Mengklik ranking & \\
\hline & 12 & & $\begin{array}{l}\text { Menyimpan hasil perankingan } \\
\text { pemasok pada periode tersebut }\end{array}$ \\
\hline Post-conditions & \multicolumn{3}{|c|}{ Ranking pemasok pada periode tertentu tersimpan dalam database } \\
\hline
\end{tabular}


Setiap usecase harus dijelaskan alur prosesnya melalui sebuah deskripsi usecase atau skenario usecase. Contoh pada usecase description login, setiap user atau aktor yang berinteraksi langsung dengan DSS harus melakukan fungsi login terlebih dahulu. Sedangkan Fungsi meranking pemasok hanya dapat diakses oleh Kepala Bagian Pembelian.

Berikutnya yaitu activity diagram. Diagram ini menunjukkan langkahlangkah dalam aliran kerja, titik-titik keputusan dalam aliran kerja, siapa yang bertanggungjawab menyelesaikan masing-masing aktivitas, dan objek-objek yang digunakan dalam aliran kerja. Activity Diagram dibuat berdasarkan usecase pada usecase diagram pada Gambar 4.

Gambar 4. Activity Diagram Perankingan Pemasok Bokar

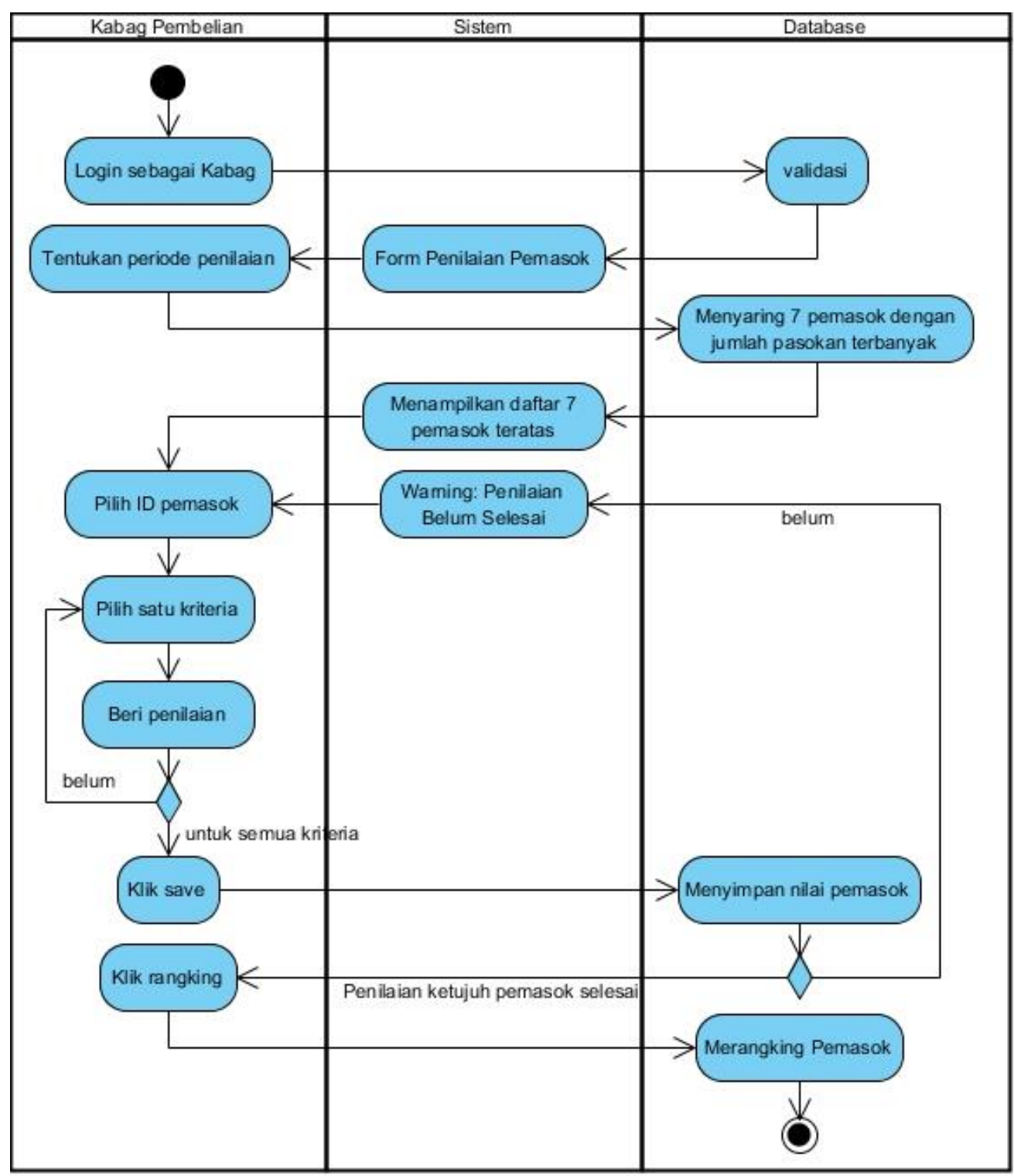


Proses perancangan database diawali dengan normalisasi data, yaitu teknik analisis data dengan cara mengelompokkan atribut-atribut data sehingga terbentuk entitas yang non-redudan, stabil, dan fleksibel. Normalisasi bertujuan untuk mengeliminasi adanya duplikasi informasi. Untuk kepentingan rancangan database bisnis, 3NF dinilai cukup memadai untuk menghasilkan tabel-tabel yang berkualitas baik. Adapun data yang akan dinormalisasi meliputi data user, data pemasok bokar, data penerimaan bokar, kriteria pemasok bokar, dan penilaian pemasok bokar.

Pada normalisasi dikenal istilah primary key dan foreign key. Sebuah primary key akan tepat memiliki satu informasi yang identik pada database. Misalnya primary key untuk data pemasok bokar adalah ID pemasok. Jadi setiap pemasok hanya memiliki satu nomor ID saja. Sedangkan foreign key menggambarkan ketergantungan parsial suatu informasi pada database. Jadi profil pemasok seperti nama, asal daerah, dan data lainnya melekat pada ID pemasok tersebut pada database. Bentuk Normal $3^{\text {rd }}$ NF dari Database Sistem Pembelian Bokar dapat dilihat pada tabel-tabel berikut:

Tabel 4. Bentuk Normal 3rd NF Data User

\begin{tabular}{|c|c|c|c|}
\hline \#Username & Password & Nama User & Jabatan \\
\hline A1 & 1234 & Endi & Direktur \\
\hline A2 & 1324 & Robi & Kabag \\
\hline A3 & 1423 & Vivi & Admin \\
\hline
\end{tabular}

Tabel 5. Bentuk Normal 3rd NF Data Pemasok Bokar

\begin{tabular}{|c|c|c|c|c|c|c|}
\hline $\begin{array}{c}\text { \#ID } \\
\text { Pemasok }\end{array}$ & $\begin{array}{c}\text { Nama } \\
\text { Pemasok }\end{array}$ & No. Hp & $\begin{array}{c}\text { Asal } \\
\text { Daerah }\end{array}$ & $\begin{array}{c}\text { Jarak Pengiriman } \\
(\mathbf{k m})\end{array}$ & $\begin{array}{c}\text { Kecepatan } \\
\text { Pengiriman }\end{array}$ & $\begin{array}{c}\text { Tanggal Mulai } \\
\text { Memasok }\end{array}$ \\
\hline 1 & Budi & $0813-6352-x x x x$ & Sijunjung & 84 & 3 jam 27 menit & $1 / 20 / 2017$ \\
\hline 2 & Anto & $0853-6290-x x x x$ & Dharmasraya & 179 & 4 jam 5 menit & $2 / 13 / 2017$ \\
\hline 3 & Wawan & $0852-6361-x x x x$ & Merangin & 222 & 8 jam 6 menit & $3 / 25 / 2018$ \\
\hline
\end{tabular}

Tabel 6. Bentuk Normal 3 ${ }^{\text {rd }}$ NF Data Penerimaan Bokar

\begin{tabular}{|c|c|c|c|c|c|}
\hline $\begin{array}{c}\text { \#ID } \\
\text { Penerimaan }\end{array}$ & $\begin{array}{c}\text { Tanggal } \\
\text { Penerimaan }\end{array}$ & $*$ Username & $\begin{array}{c}* \text { ID } \\
\text { Pemasok }\end{array}$ & $\begin{array}{c}\text { Jumlah } \\
\text { Pasokan (kg) }\end{array}$ & KKK \\
\hline 1 & $4 / 1 / 2017$ & A3 & 1 & 100 & 56 \\
\hline 2 & $4 / 1 / 2017$ & A3 & 2 & 80 & 60 \\
\hline 3 & $4 / 2 / 2017$ & A3 & 1 & 50 & 58 \\
\hline 4 & $4 / 3 / 2017$ & A3 & 3 & 125 & 52 \\
\hline
\end{tabular}


Tabel 7. Bentuk Normal 3 ${ }^{\text {rd }}$ NF Kriteria Pemasok Bokar

\begin{tabular}{|c|c|c|c|c|c|c|c|c|}
\hline \multirow{2}{*}{$\begin{array}{c}\text { \#Kode } \\
\text { Kriteria }\end{array}$} & \multirow{2}{*}{ Kriteria } & \multirow{2}{*}{$\begin{array}{c}\text { Bobot } \\
\text { Kriteria }\end{array}$} & \multicolumn{5}{|c|}{ Bilangan Fuzzy } & \multirow{2}{*}{ Kategori } \\
\hline & & & $\mathbf{0}$ & 0.25 & 0.5 & 0.75 & 1 & \\
\hline A & Tebal Bongkahan/dimensi Bokar & 0.05 & Sangat tebal & Tebal & Cukup Tebal & Tipis & Sangat tipis & - \\
\hline B & Kebersihan Bokar & 0.45 & Sangat kotor & Kotor & Cukup bersih & Bersih & Sangat bersih & + \\
\hline $\mathrm{C}$ & Kadar Air (KKK) & 0.36 & $0-20 \%$ & $21-40 \%$ & $41-60 \%$ & $61-80 \%$ & $81-100 \%$ & + \\
\hline $\mathrm{D}$ & Konsistensi Kualitas & 0.14 & $\begin{array}{c}\text { Sangat tidak } \\
\text { Konsisten }\end{array}$ & $\begin{array}{c}\text { Tidak } \\
\text { konsisten }\end{array}$ & $\begin{array}{l}\text { Cukup } \\
\text { konsisten }\end{array}$ & Konsisten & $\begin{array}{c}\text { Sangat } \\
\text { Konsisten }\end{array}$ & + \\
\hline
\end{tabular}

Tabel 8. Bentuk Normal 3rd NF Penilaian Pemasok Bokar

\begin{tabular}{|c|c|c|c|c|c|c|c|c|c|c|c|}
\hline $\begin{array}{c}\text { \#Periode Penerimaan } \\
\text { (Bulan/Tahun) }\end{array}$ & *Username & $\begin{array}{c}\text { *ID } \\
\text { Pemasok }\end{array}$ & $\begin{array}{c}\text { *Kode } \\
\text { Kriteria A A }\end{array}$ & $\begin{array}{c}\text { Interval } \\
\text { Penilaian A }\end{array}$ & $\begin{array}{c}\text { *Kode } \\
\text { Kriteria B B }\end{array}$ & $\begin{array}{c}\text { Interval } \\
\text { Penilaian B }\end{array}$ & $\begin{array}{c}\text { *Kode } \\
\text { Kriteria C }\end{array}$ & $\begin{array}{c}\text { Interval } \\
\text { Penilaian C C }\end{array}$ & $\begin{array}{c}\text { *Kode } \\
\text { Kriteria D }\end{array}$ & $\begin{array}{c}\text { Interval } \\
\text { Penilaian D }\end{array}$ & $\begin{array}{c}\text { Rangking } \\
\text { Pemasok }\end{array}$ \\
\hline Apr-17 & $\mathrm{A} 2$ & 1 & 0.05 & 1 & 0.45 & 0.25 & 0.36 & 0.75 & 0.14 & 0.5 & 1 \\
\hline Apr-17 & $\mathrm{A} 2$ & 2 & 0.05 & 0.5 & 0.45 & 0.25 & 0.36 & 0.5 & 0.14 & 1 & 3 \\
\hline Apr-17 & $\mathrm{A} 2$ & 3 & 0.05 & 0.75 & 0.45 & 0.5 & 0.36 & 1 & 0.14 & 0.75 & 2 \\
\hline
\end{tabular}

Keterangan tabel:

\begin{tabular}{|l|}
\hline \#Primary Key \\
*Foreign Key \\
Hitungan matematis \\
\hline
\end{tabular}

Selanjutnya melalui class diagram akan digambarkan struktur sistem dan objek-objek beserta hubungan satu sama lain. Kelas-kelas yang ada pada struktur sistem harus dapat melakukan fungsi-fungsi yang dibangun sesuai dengan analisis kebutuhan sistem. Entity Relationship Diagram (ERD) menggambarkan kebutuhan informasi atau jenis informasi yang akan disimpan dalam database seperti primary key dan foreign key.

\section{E. KESIMPULAN}

Pada studi ini juga dihasilkan DSS penilaian pemasok bokar. DSS ini dapat memudahkan pengambil keputusan dalam menelusuri dokumen-dokumen terkait sistem pembelian bokar serta membantu proses perangkingan pemasok menjadi lebih komprehensif dan lebih objektif. Salah satu kelebihan yang ditawarkan yaitu DSS dapat mengakomodasi perbedaan dan perubahan kriteria penilaian pemasok bokar sesuai pertimbangan setiap industri crumb rubber di Sumatera Barat. Berdasarkan perhitungan pada DSS, kriteria kadar air (KKK) memperoleh bobot tertinggi yaitu 0,18, diikuti kebersihan bokar $(0,15)$, dan konsistensi kualitas $(0,10)$. Sementara kinerja masa lalu hanya memperoleh bobot 
0,05. Kemudian rangking pemasok secara beturut-turut yaitu AMS, Fafadiandri, Aseng, Kodir, dan Ati dengan nilai preferensi $\left(V_{i}\right)$ 0.72, 0.58, 0.41, 0.32, dan 0.23.

\section{F. DAFTAR PUSTAKA}

Akbar, P.G. “Usulan Indikator Evaluasi Pemasok Dalam Penetapan Bidder List: Studi Kasus Pengadaan Jasa PT. Semen Padang." Jurnal Optimasi Sistem Industri 14, no. 1 (2015): 39-54.

Ayhan, M.B. "A Fuzzy Ahp Approach For Supplier Selection Problem: A Case Study In A Gearmotor Company." International Journal of Managing Value and Supply Chains (IJMVSC) 4, no. 3 (2013): 11-23.

Elwizalina. "Penilaian Supplier Bokar Pada PT Kilang Lima Gunung Dengan Metoda Analytical Hierarchy Process." Sekolah Tinggi Teknologi Industri, 2008.

Erni, N, M.S Maarif, N.S Indrasti, Machfud, and S Honggono. "Rekayasa Sistem Manajemen Ahli Perencanaan Produksi Karet Spesifikasi Teknis." Inovisi 7, no. 1 (2011): 25-32.

Hadiguna, R.A. "Decision Support System of Performance Assessment for Sustainable Supply Chain Management." International Journal of Green Computing 4, no. 2 (2013): 24-37.

Khung, D, and H Zhu. Software Verification and Validation (Wiley Encyclopedia of Computer Science and Engineering). London: John Wiley \& Sons, Inc, 2008.

Mendoza, A, and J.A Ventura. "An Effective Method to Supplier Selection and Order Quantity Allocation." International Journal of Business and Systems Research 2, no. 1 (2008): 1-15.

Setiawan, A, and R Wijaya. Perancangan Dan Pembuatan Aplikasi Decision Support System Pada Departemen HRD Dan Pembelian Dengan Menggunakan Metode Analytical Hierarchy Process (AHP). Surabaya: Universitas Kristen Petra, 2007.

Turban, J.E, and T.P Liang. Decision Support System and Intelligent Systems. 7th ed. New Delhi: Prentice Hal of India Private Limited, 2005. 